\title{
Investigation of Refrigerant R134a Two Phase Flow Heat Transfer in Vertical Heat Exchanger Channel https://doi.org/10.32792/utq/uti/vol14/1/5
}

\author{
Abdullah Adel Ibrahim ${ }^{\mathrm{a}}$,Ahmed J. Hamad ${ }^{\mathrm{b}}$ and Johain J. \\ Faraj \\ a , b , ',Engineering Technical College-Baghdad, Middle \\ Technical University, Emails: ${ }^{a}$, \\ (Abdullah.adel59@yahoo.com) \\ b, (elhamad@mtu.edu.iq) \\ c, (Johaintech@mtu.edu.iq)
}

\begin{abstract}
Two phase flow boiling heat transfer and pressure drop in the vertical evaporator tube section of refrigeration system have been experimentally investigated using refrigerant R134a as a working fluid. The objective of the present work is to investigate experimentally the effect of heat flux, mass flux, vapor quality and saturation temperature on refrigerant flow boiling heat transfer characteristics in the evaporator of refrigeration system. These investigated parameters have significant impacts to enhance the thermal performance of the evaporator. The experimental investigations were conducted in smooth copper tube with inner diameter $5.8 \mathrm{~mm}$ and $600 \mathrm{~mm}$ length under different test conditions. The test conditions considered in this study were, for heat flux of 7.718-32.78 $\mathrm{kW} / \mathrm{m}^{2}$, mass flux of $97.3-148.7 \mathrm{~kg} / \mathrm{m}^{2} . \mathrm{s}$, saturation temperature of 20.58 to $-15.68{ }^{\circ} \mathrm{C}$ and vapor quality of $0.3-1$. It can be concluded from the results that, the average heat transfer coefficient at relatively greater mass flux $148.7 \mathrm{~kg} / \mathrm{m}^{2}$.s was higher in range of $21 \%$ compared to other mass fluxes at constant test conditions. The relatively higher value of heat transfer coefficient was observed at heat flux $32.78 \mathrm{~kW} / \mathrm{m}^{2}$ with average increase of $19 \%$ compared to the relatively lower value $23.38 \mathrm{~kW} / \mathrm{m}^{2}$. The enhancement in local heat transfer coefficient at saturation temperature -
\end{abstract}




\section{University of Thi-Qar Journal Vol.14 No.3 SEP 2019 Web Site: https://jutq.utq.edu.iq/index.php/main \\ Email: utj@utq.edu.iq}

$15.68^{\circ} \mathrm{C}$ was higher by about $12 \%$ than that for the relatively lower temperature $-20.58^{\circ} \mathrm{C}$. The effect of increase in mass flux and heat flux on pressure drop in the evaporator tube was about $9 \%$ and $7.5 \%$ respectively.

Key Words: Heat transfer, Flow boiling, Pressure drop, Heat flux.

\section{الخلاصة}

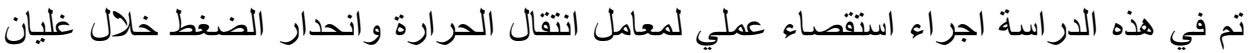

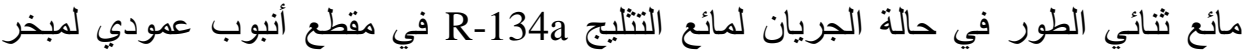

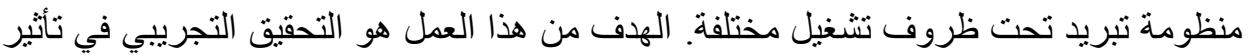

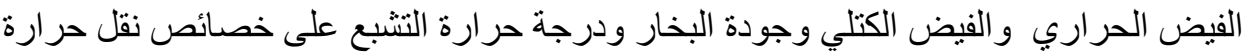

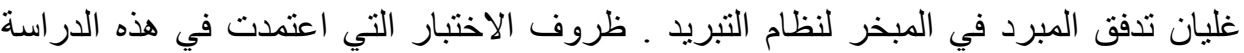

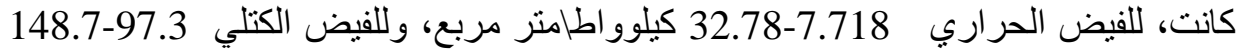

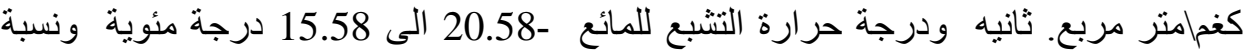

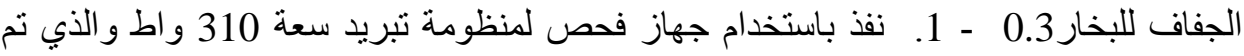

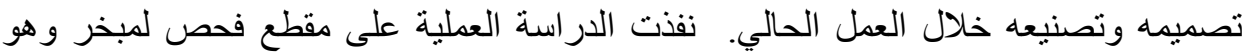

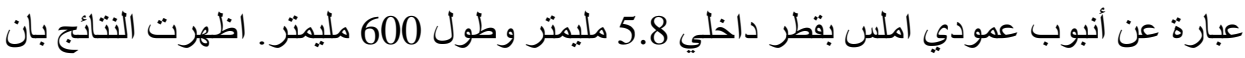

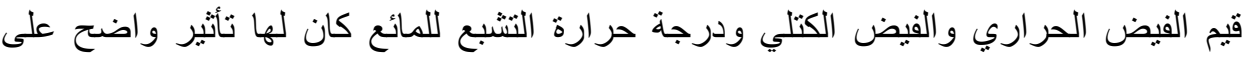

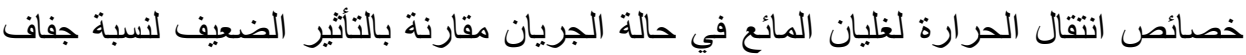

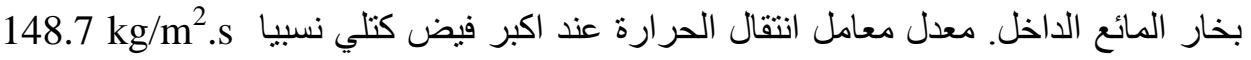

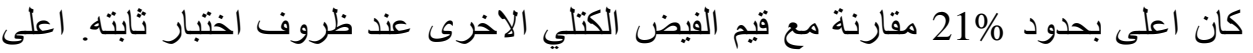

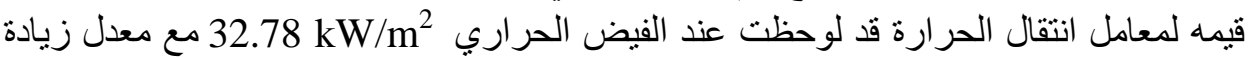
بحدود 19\% مقارنة مع ادنى قيمة نسبيا 23.38 kW/m².

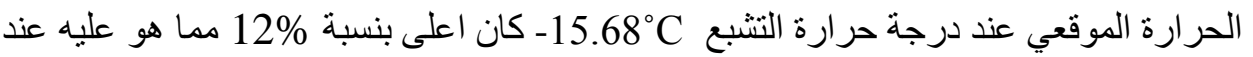
ادنى درجة حرارة نسبيا 20.58 C.

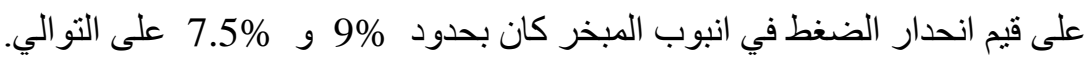

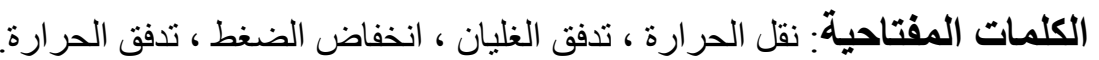

\section{Introduction}

Boiling is the process of a substance phase change from liquid into vapor by the increase of heat. Due to its ability to transfer heat at a very low 


\section{University of Thi-Qar Journal Vol.14 No.3 SEP 2019 \\ Web Site: https://jutq.utq.edu.iq/index.php/main \\ Email: utj@utq.edu.iq}

temperature, boiling heat transfer is vital in many industrial applications such as, power stations, refrigeration and air conditioning systems, cooling of lasers, cooling of electronics, nuclear reactors and other high heat flux applications [1]. Dissimilar types of boiling can be classified according to the geometric situation and to the mechanism in process. [2]. Boiling can be classified into, pool boiling and flow boiling. Boiling is called pool boiling in the lack of bulk fluid flow. Boiling is called flow boiling in the presence of bulk fluid flow [3]. The flow boiling heat transfer process was investigated by many researchers in many thermal components and energy systems. Chen et al. [4] , studied the two-phase flow patterns in vertical small diameter tubes 1.10, 2.01, 2.88 and 4.26 $\mathrm{mm}$ with refrigerant R134a as the working fluid. Various flow pattern maps were presented at different pressures. The results showed that the Churn-annular and slug churn boundaries depend on diameter and pressure, while the dispersed bubble-churn and bubbly-slug were less affected by diameter and pressure. Xiaorong et al. [5], investigated experimentally the boiling heat transfer in two stainless steel tubes with diameter $4.26 \mathrm{~mm}$ and $2.01 \mathrm{~mm}$ respectively using refrigerant R-134a. The range of mass flux $100-500 \mathrm{~kg} / \mathrm{m}^{2}$.s, pressure $8-14$ bar, quality up to 0.9 and heat flux $13-150 \mathrm{~kW} / \mathrm{m}^{2}$. The results showed that for the 4.26 $\mathrm{mm}$ tube when the vapor quality was less than about $40 \%$ to $50 \%$, the heat transfer coefficient increases with heat flux and system pressure but did not change with vapor quality. Mahmoud et al. [6], conducted a comparison between experimental flow boiling heat transfer results obtained using two different tubes of $150 \mathrm{~mm}$ length, a seamless cold drew stainless steel tube of $1.1 \mathrm{~mm}$ inner diameter and $1.16 \mathrm{~mm}$ inner diameter welded stainless steel tube, with vertically upwards flow direction. The operating conditions considered were, for a mass flux of $300 \mathrm{~kg} / \mathrm{m}^{2}$.s, system pressure $8 \mathrm{bar}$, inlet sub-cooling $5 \mathrm{~K}$ and up to 0.9 exit quality. The results presented the variation of local heat transfer coefficient with local quality at different conditions and investigated the effect of tube inner surface roughness on the heat transfer characteristics. Ali et al. [7], studied experimentally the flow boiling heat transfer in a stainless steel mini channel of $1.70 \mathrm{~mm}$ internal diameter and a heated length of $220 \mathrm{~mm}$ using R134a as a working fluid. The test conditions 


\section{University of Thi-Qar Journal Vol.14 No.3 SEP 2019 \\ Web Site: https://jutq.utq.edu.iq/index.php/main \\ Email: utj@utq.edu.iq}

were for saturation temperatures of $27^{\circ} \mathrm{C}$ and $32^{\circ} \mathrm{C}$, mass flux from 50 $\mathrm{kg} / \mathrm{m}^{2} \mathrm{~s}$ to $600 \mathrm{~kg} / \mathrm{m}^{2}$.s, and heat flux ranged from $2 \mathrm{~kW} / \mathrm{m}^{2}$ to 156 $\mathrm{kW} / \mathrm{m}^{2}$. The results show that the heat transfer coefficient increases with the increase of wall heat flux, while mass flux and vapor quality have no significant effects. Increasing the system pressure enhanced the heat transfer coefficient, and the heat transfer coefficient is reduced as dry out is reached. Emily et. al. [8], conducted experiments to compare the flow boiling heat transfer and pressure drop results between the refrigerant R134a and refrigerant R245fa, in a vertical stainless steel tube with an inner diameter of $1.1 \mathrm{~mm}$ and a heated length of $150 \mathrm{~mm}$. The results show that the pressure drop of R245fa is higher by up to $300 \%$ compared to that of R134a at similar conditions. While the effect of mass flux and heat flux on the local flow boiling heat transfer coefficient was different. Heat transfer coefficients of R245fa showed a greater dependence on vapor quality. Fang [9], proposed a new correlation to predict the R134a two-phase flow boiling heat transfer based on the experimental data from 19 published papers. The new correlation takes advantage of the newly defined dimensionless number $(\mathrm{Fa})$ proposed by Fang which is highly related to flow boiling heat transfer. The new correlation also shows high prediction accuracy for other refrigerants such as CO2, R22, R410a and R236fa. Mancin et al. [10], investigated the flow boiling heat transfer and pressure drop for refrigerant R134a inside a small micro-fin tube with an internal diameter of $3.4 \mathrm{~mm}$. The experimental facility is developed to study both single and two-phase heat transfer processes. The experimental measurements were carried out at different test conditions. The results show that the flow boiling heat transfer is controlled by the two wellknown phase change heat transfer mechanisms, nucleate boiling and twophase forced convection. At a heat flux of $10 \mathrm{~kW} / \mathrm{m}^{2}$, the dry out phenomenon doesn't occur at any mass velocity. The results also show the effects of the vapor quality and mass velocity on the frictional pressure gradients. Wei Li et al. [11], conducted the saturated flow boiling experiments to investigate the influence of surface wettability on the hydraulic and thermal transport performance in a rectangular micro channel with deionized water as the working fluid. Parametric experimental studies were carried out with the inlet vapor quality varied 


\section{University of Thi-Qar Journal Vol.14 No.3 SEP 2019 \\ Web Site: https://jutq.utq.edu.iq/index.php/main \\ Email: utj@utq.edu.iq}

from 0.03 to 0.1 and the wall heat fluxes from 4 to $20 \mathrm{~W} / \mathrm{cm}^{2}$ and mass fluxes ranging from 120 to $360 \mathrm{~kg} / \mathrm{m}^{2}$.s. Results indicated that, a reduction in heat transfer was observed for the bared silicon wafer surface with increased inlet vapor quality and heat flux. The objective of the present work is to investigate experimentally the effect of heat flux, mass flux, vapor quality and saturation temperature on flow boiling heat transfer coefficient and pressure drop of refrigerant R-134a in the evaporator vertical test section. These investigated parameters have significant impacts to enhance the thermal performance of the evaporator in the refrigeration system.

\section{Experimental Setup}

The experimental setup is consisting of hermetic compressor with $125 \mathrm{~W}$ capacity, water-cooled condenser, refrigerant flow meter, capillary tube, pre-heater, post-heater and test section which simulates the evaporator of the refrigeration system. Two visualization sections are installed at inlet and outlet of the test section with $150 \mathrm{~mm}$ length glass tube of the same internal diameter of the test section as shown in Fig.1 and Fig.2. The evaporator section in the test rig system is represent a vertical smooth copper tube with an inside diameter of $5.8 \mathrm{~mm}$, wall thickness of 1.05 $\mathrm{mm}$ and $600 \mathrm{~mm}$ length. Electrical heater is used to simulate the thermal load applied on the evaporator section using a $350 \mathrm{~W}$ heating wire with length of $2.5 \mathrm{~m}$. The thermocouples are fixed with equal distance on the test section and the tube was wrapped with insulation material to minimize the heat loss caused by convection and radiation heat transfer to the ambient. The heat flux was regulated by varying the input electrical power using variable power supply (variac). The inlet and outlet of the evaporator tube are connected with two transparent tubes of $5.8 \mathrm{~mm}$ inner diameter and $150 \mathrm{~mm}$ length to visualize the flow pattern as shown in Fig.3. 
University of Thi-Qar Journal Vol.14 No.3 SEP 2019

Web Site: https://jutq.utq.edu.iq/index.php/main

Email: utj@utq.edu.iq

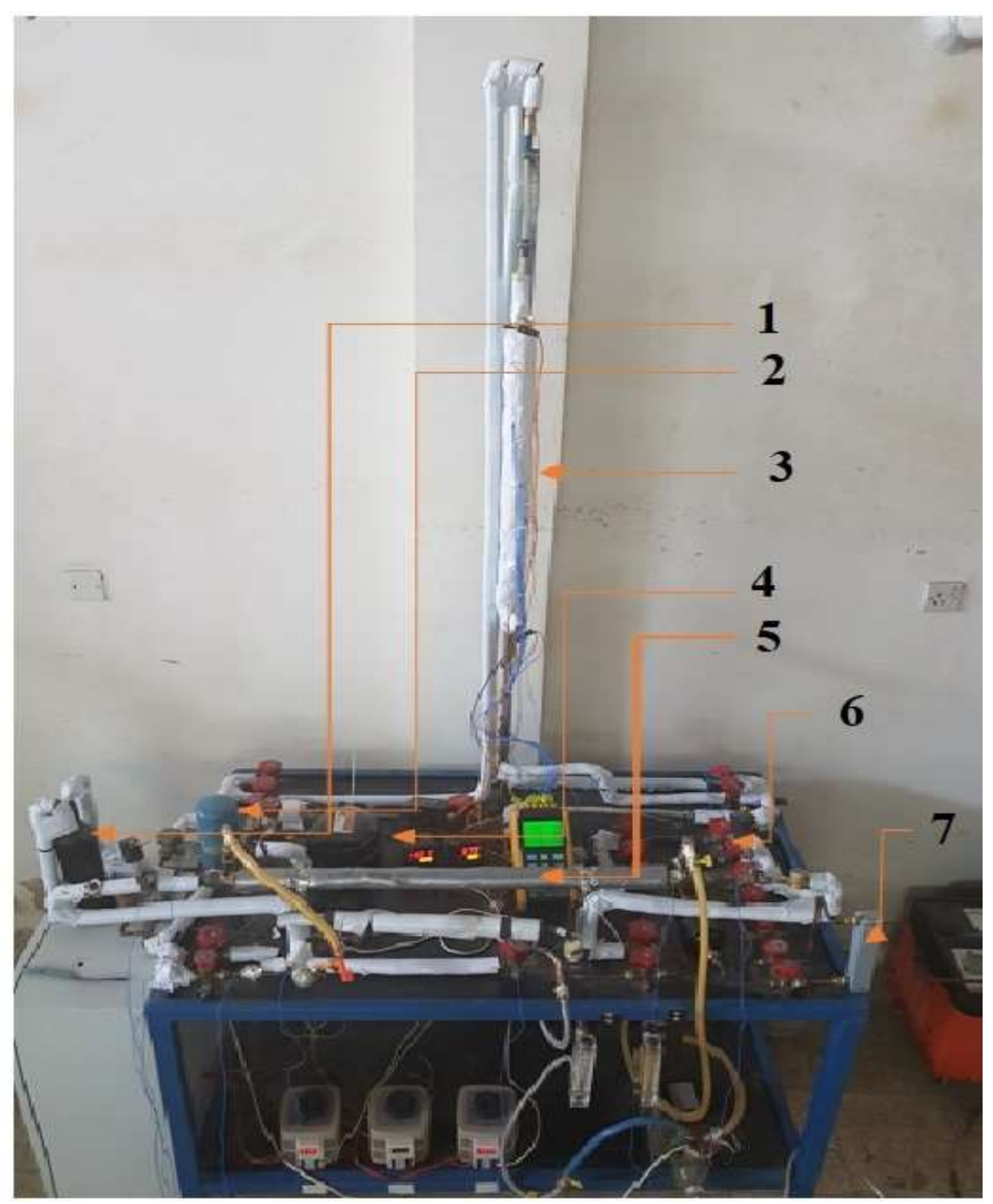

\begin{tabular}{|l|l|}
\hline Item & Description \\
\hline 1 & Accumulator \\
\hline 2 & Oil Separator \\
\hline 3 & Evaporator \\
\hline 4 & Compressor \\
\hline 5 & Condenser \\
\hline 6 & Capillary Tubes \\
\hline 7 & Flow Meter \\
\hline
\end{tabular}




\section{University of Thi-Qar Journal Vol.14 No.3 SEP 2019 \\ Web Site: https://jutq.utq.edu.iq/index.php/main \\ Email: utj@utq.edu.iq}

Fig 1. Test Rig.

\section{Theoretical Analysis}

The heat transfer rates supplied by the electric coil to the outside wall surface of the copper tube in the evaporator section and preheater $\left(\dot{Q}_{e v}, \dot{Q}_{p r e}\right)$ are calculated by:

$\dot{Q}_{e v}=V \cdot I \cdot \eta$

(1)

Where $(\eta)$ is the heating coefficient that reflects the efficiency of the heat transfer process in the test section which is based on the electrical power input $\left(P_{e l . i}\right)$ to the heater coil and determined by the following equation:

$\eta=\frac{\dot{m} \cdot\left(h_{o}-h_{i}\right)}{P_{\text {el.i }}}$

The heat flux supplied from the inside wall surface of the evaporator tube $\left(q_{e v}\right)$ to the refrigerant is calculated by:

$\dot{q}_{e v}=\frac{\dot{Q}_{e v}}{\pi \cdot d i \cdot L_{t s}}$

The local heat transfer coefficient of the refrigerant flow boiling in the test section (evaporator tube) is calculated by [2]:

$h_{z}=\frac{\dot{q}_{e v}}{T_{w . i}-T_{r e f}}$

$T_{w . i} \cdot T_{r e f}$ : Inner wall and refrigerant saturation temperatures at each axial position (z) along the test section tube $\left({ }^{\circ} \mathrm{C}\right)$.

For each axial location ( $\mathrm{z}$ ) along the test section tube, the external wall temperature $T_{w o}$ was assumed to be the average of measured temperatures around the tube cross section and calculated by: 
$T_{w o}=\frac{T_{w . t}+T_{w . b}}{2}$

(5)

$T_{w . t}, T_{w . b}$ : The external wall temperatures at the top and bottom of the test section tube respectively $\left({ }^{\circ} \mathrm{C}\right)$.

The mean inner wall temperature at each position $(\mathrm{z})\left(T_{\text {wi.z }}\right)$ is calculated using one dimensional heat conduction across tube wall by:

$T_{w i . z}=T_{w . o}-\dot{Q}_{e v} \cdot R_{w}$

(6)

Thermal resistance $R_{w}$ of the test section tube is calculated by:

$R_{w}=\frac{\operatorname{Ln}\left(\frac{d_{o}}{d_{i}}\right)}{2 \pi \cdot k_{c u} \cdot L_{z}}$

The local saturation temperature $T_{\text {sat.z }}$ at each position (z) along the test section tube is calculated based on local saturation pressure $P_{\text {sat.z }}$ which is expressed by:

$P_{\text {sat.z }}=P_{i . e v}-\Delta p \cdot \frac{L_{z}}{L_{t s}}$

(8) 
University of Thi-Qar Journal Vol.14 No.3 SEP 2019

Web Site: https://jutq.utq.edu.iq/index.php/main

Email: utj@utq.edu.iq

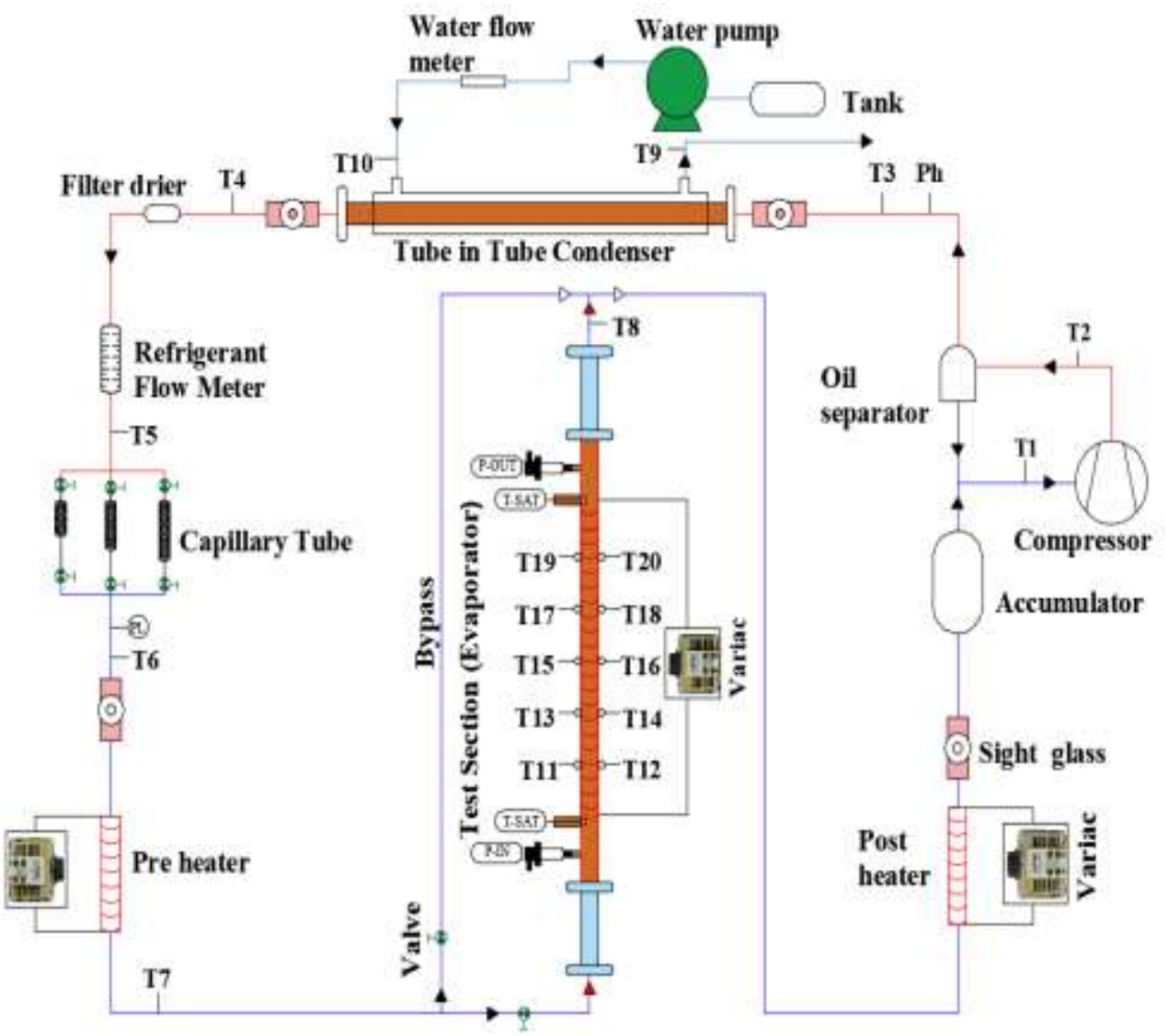

Fig 2. Schematic diagram of the test rig. 
University of Thi-Qar Journal Vol.14 No.3 SEP 2019

Web Site: https://jutq.utq.edu.iq/index.php/main

Email: utj@utq.edu.iq
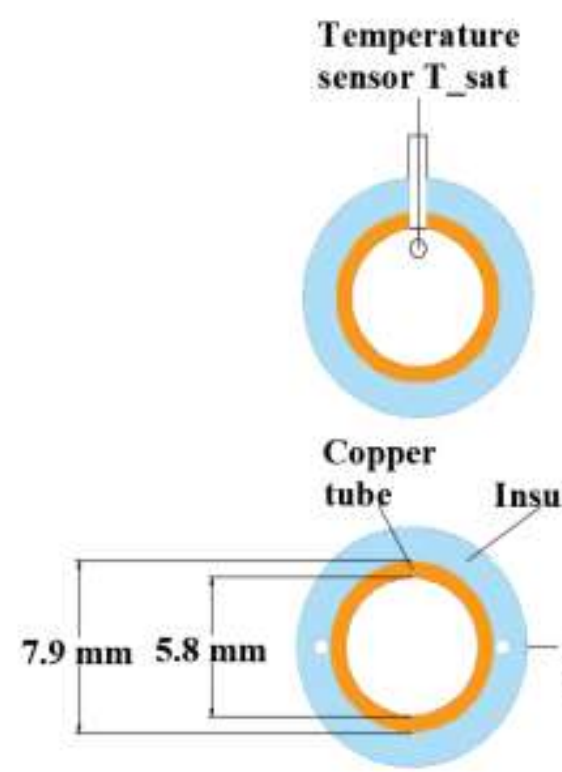

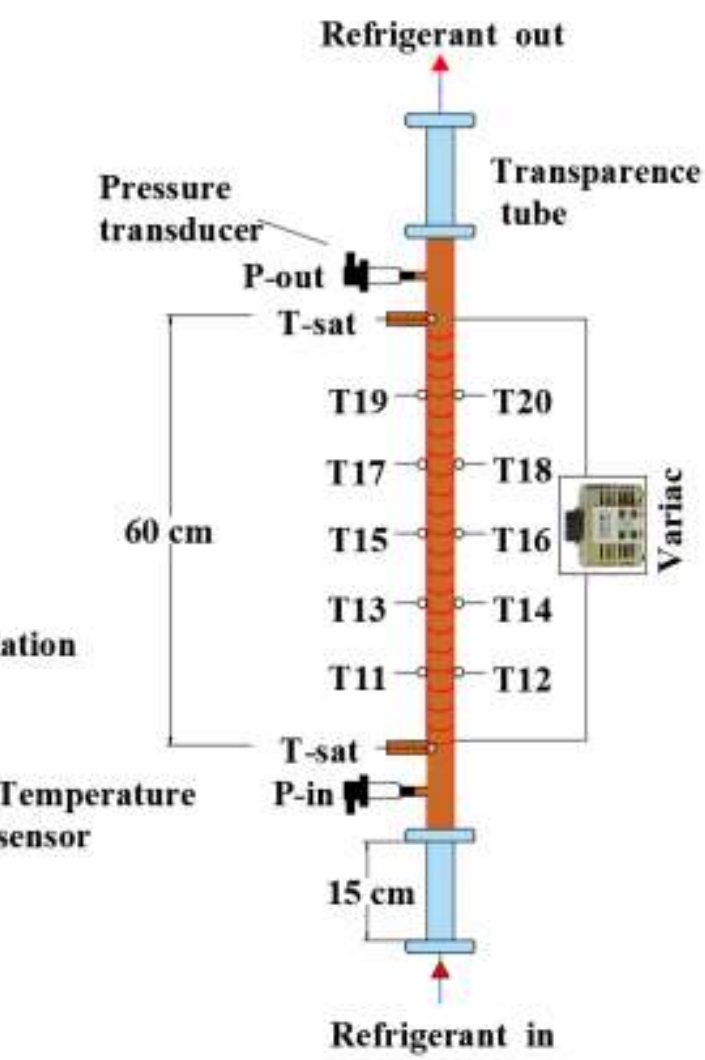

Fig 3. Schematic diagram of the test section (evaporator tube).

Where: $P_{i . e v}$ is the refrigerant pressure at inlet of the test section, $\Delta p$ is the refrigerant pressure difference between inlet and outlet of the test section.

The vapor quality at the inlet of the test section tube $\left(x_{i}\right)$ is expressed in term of the local enthalpy as follows [13]:

$x_{i}=\frac{h_{i}-h_{l . i}}{h_{f g . i}}$

(9)

The specific enthalpy of the refrigerant at the inlet of the test section $h_{i . t s}$ represents the specific enthalpy of the refrigerant at the outlet of 


\section{University of Thi-Qar Journal Vol.14 No.3 SEP 2019 \\ Web Site: https://jutq.utq.edu.iq/index.php/main \\ Email: utj@utq.edu.iq}

preheater, which can be determined by applying an energy balance on the preheater as follows:

$h_{i . t s}=h_{i . p r}+\frac{\dot{Q}_{p r}}{\dot{m}}$

Vapor quality (dryness fraction) of the refrigerant at each position $\left(x_{z}\right)$ is calculated by using a linear relation along test section length:

$x_{z}=x_{i}+\Delta x \cdot L_{z}$

Vapor quality difference $\Delta x$ of the refrigerant between inlet and outlet of the evaporator tube can be expressed by:

$\Delta x=\frac{x_{o}-x_{i}}{L_{t s}}$

Outlet vapor quality of the refrigerant in the test section tube is calculated by:

$x_{o}=\frac{h_{o . t s}-h_{l . o}}{h_{f g . o}}$

Outlet specific enthalpy of the refrigerant in the test section tube $h_{o . t s}$ is determined by applying an energy balance on the test section:

$h_{o . t s}=h_{i . t s}+\frac{\dot{Q}_{e v}}{\dot{m}}$

Total pressure gradient in the test section tube is calculated by [1]:

$-\frac{d p}{d z}=-\frac{\Delta p}{L_{t s}}$

$\Delta p=\Delta p_{f r} \quad+\quad \Delta p_{m} \quad+\quad \Delta p_{s t}$ 


\section{University of Thi-Qar Journal Vol.14 No.3 SEP 2019 \\ Web Site: https://jutq.utq.edu.iq/index.php/main \\ Email: utj@utq.edu.iq}

Where:

$\Delta \mathrm{p}$ : Total pressure drop of the refrigerant flow in the test section tube $(\mathrm{kPa})$ which is determined experimentally using the following equation:.

$$
=\quad P_{\text {o.ev }} \quad-\quad P_{\text {i.ev }}
$$

$\Delta \mathrm{p}_{\mathrm{fr}}$ : Frictional pressure drop of the refrigerant flow due to shear at the tube surface and at the vapor-liquid interface in the test section $(\mathrm{kPa})$.

$\Delta \mathrm{p}_{\mathrm{m}}$ : Momentum pressure drop due to the acceleration of the two-phase refrigerant flow in the test section $(\mathrm{kPa})$.

$\Delta \mathrm{p}_{\mathrm{st}}$ : Pressure drop of the refrigerant flow due to the static pressure change in the test section tube $(\mathrm{kPa})$ and can be calculated by [12]:

$\Delta \mathrm{p}_{\mathrm{st}}=\left[\alpha \rho_{v}+(1-\alpha) \rho_{l}\right] g \sin \emptyset$

Where: $\varnothing$ is the angle of the evaporator tube with horizontal plane $\left(90^{\circ}\right)$, and $\alpha$ is the void fraction which can be determined as per homogenous model [12] as follow:

$\alpha=\left[1+\left(\frac{1-x}{x}\right)\left(\frac{\rho_{v}}{\rho_{l}}\right)^{2 / 3}\right]^{-1}$

Momentum pressure drop $\Delta \mathrm{p}_{\mathrm{m}}$ is determined by:

$\Delta \mathrm{p}_{\mathrm{m}}=$

$$
G^{2}\left[\frac{v_{v^{*} x^{2}}}{\alpha}+\frac{v_{l}(1-x)^{2}}{(1-\alpha)}\right]
$$

Frictional pressure drop of the refrigerant flow $\Delta \mathrm{p}_{\mathrm{fr}}$ is determined by:

$\Delta p_{f r} \quad=\quad \Delta p-\Delta p_{m} \quad-\quad \Delta p_{s t}$

\section{Results and Discussions}




\section{University of Thi-Qar Journal Vol.14 No.3 SEP 2019 \\ Web Site: https://jutq.utq.edu.iq/index.php/main \\ Email: utj@utq.edu.iq}

The experimental investigations of the refrigerant R134a flow boiling heat transfer coefficient and pressure drop in the evaporator test section are conducted within test conditions in the range of $(7.718-32.78) \mathrm{kW} / \mathrm{m}^{2}$ for heat flux, $(97.3-148.7) \mathrm{kg} / \mathrm{m}^{2} . \mathrm{s}$ for mass flux, vapor quality $(0.3-1)$ and saturation temperature $(-20$ to -15$){ }^{\circ} \mathrm{C}$ as shown in the Table 1 .

Table 1 Test conditions considered in the present study

\begin{tabular}{|c|l|c|c|c|c|c|}
\hline No & $\begin{array}{l}\text { Mass } \\
\left(\mathrm{kg} / \mathrm{m}^{2} . \mathrm{s}\right)\end{array}$ & \multicolumn{5}{|c|}{ Flux } \\
\hline 1 & 97.3 & 7.718 & 11.75 & 16.48 & 23.38 & 32.78 \\
\hline 2 & 112.5 & 7.718 & 11.75 & 16.48 & 23.38 & 32.78 \\
\hline 3 & 148.7 & 7.718 & 11.75 & 16.48 & 23.38 & 32.78 \\
\hline & Range of vapor quality: $\mathrm{X}=0.3-1$ \\
\hline & Rang of evaporating temperature: -20.58 to -15.68 \\
\hline
\end{tabular}

\subsection{Characteristics of Refrigerant Flow Boiling}

The variation of heat flux with wall-refrigerant temperature difference of flow boiling for several mass fluxes $97.3,112.5$ and $148.7 \mathrm{~kg} / \mathrm{m}^{2} . \mathrm{s}$ is shown in Fig 4. It can be seen for the range of $(15-33){ }^{\circ} \mathrm{C}$ temperature difference, the dominance of nucleate and forced convective contributions of flow boiling heat transfer was evident. The observed large heat fluxes in this region are attributed to the combined effect of liquid entrainment and evaporation. The variation of the vapor quality during refrigerant flow boiling process along the test section tube is shown in the Fig $\mathbf{5}$ with fixed mass flux $112.5 \mathrm{~kg} / \mathrm{m}^{2}$.s and different heat fluxes. It can be observed that the vapor quality increases with the normalized tube length as a result of the phase change from liquid into vapor. The higher vapor quality was observed at relatively higher heat flux $32.78 \mathrm{~kW} / \mathrm{m}^{2}$. 
University of Thi-Qar Journal Vol.14 No.3 SEP 2019

Web Site: https://jutq.utq.edu.iq/index.php/main

Email: utj@utq.edu.iq

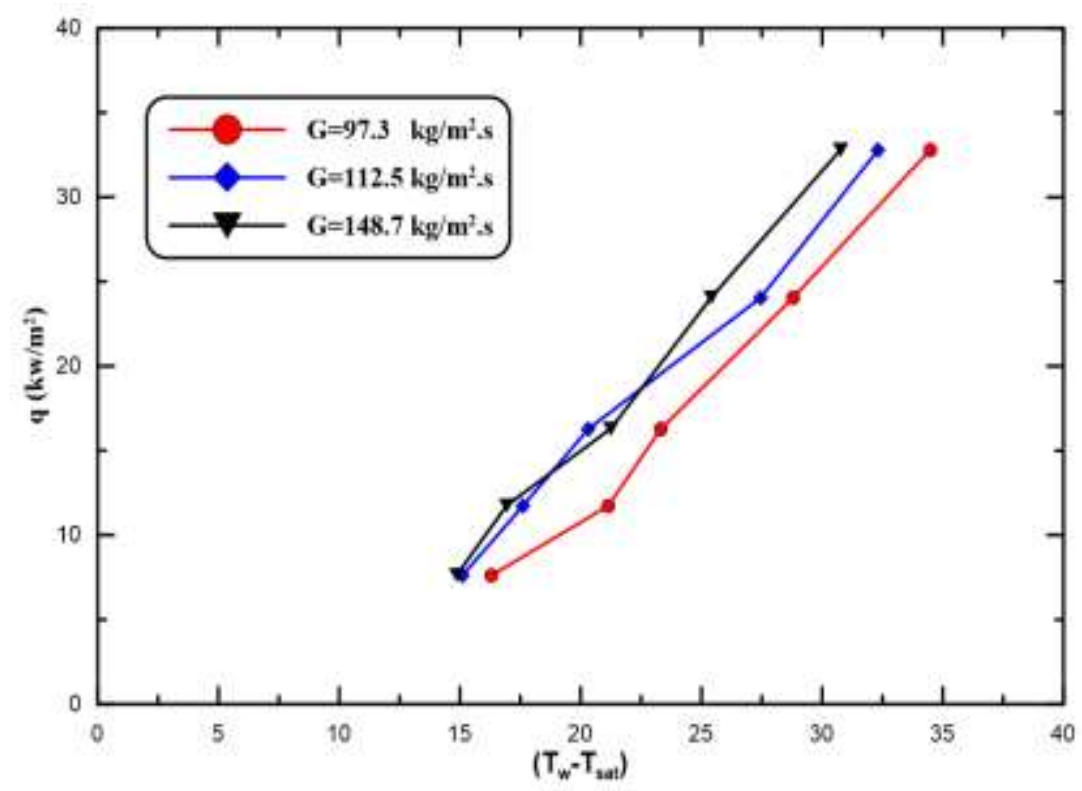

Fig 4. Variation of heat flux with wall-refrigerant temperature difference for various mass fluxes $97.3,112.5$ and $148.7 \mathrm{~kg} / \mathrm{m}^{2} . \mathrm{s}$.

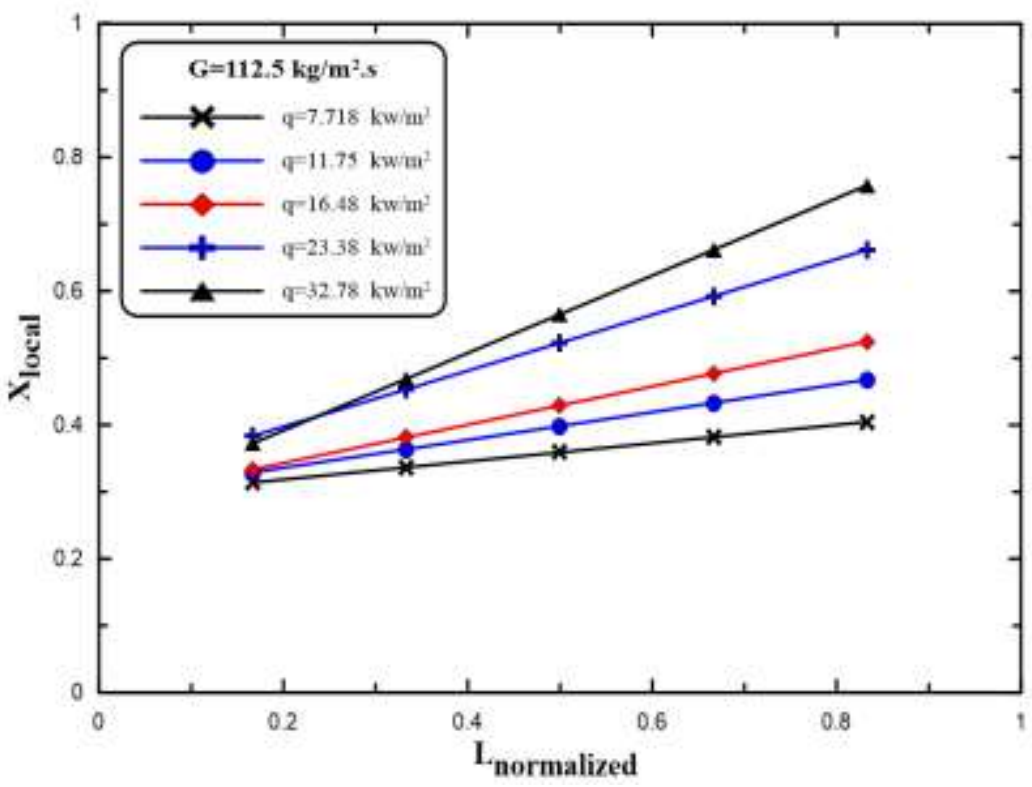

Fig 5. Refrigerant vapor quality as a function of the normalized length of the test section tube at $\mathrm{G}=112.5 \mathrm{~kg} / \mathrm{m}^{2} . \mathrm{s}$ and different heat fluxes. 
University of Thi-Qar Journal Vol.14 No.3 SEP 2019

Web Site: https://jutq.utq.edu.iq/index.php/main

Email: utj@utq.edu.iq 


\subsection{Effect of Heat Flux on Heat Transfer}

The effect of heat flux measured in the range of 7.718 to $32.78 \mathrm{~kW} / \mathrm{m}^{2}$ on flow boiling local heat transfer coefficient at fixed mass fluxes 97.3 and $148.7 \mathrm{~kg} / \mathrm{m}^{2}$.s is shown in Fig 6 and Fig 7. It can be noticed that the heat transfer coefficient is higher at the low vapor quality and continuously decreases with vapor quality for all the values of heat flux due to the nucleate and convective boiling contributions at this ranges of vapor quality and difference of wall-refrigerant temperature. The heat transfer coefficient was directly proportional to heat flux and relatively higher value of heat transfer coefficient was observed at heat flux $32.78 \mathrm{~kW} / \mathrm{m}^{2}$. According to Newton's law of convection heat transfer, the increase in heat flux at constant tube surface-refrigerant temperature difference will enhance the value of heat transfer coefficient. A similar behavior of heat transfer coefficient can be observed for mass flux $148.7 \mathrm{~kg} / \mathrm{m}^{2}$.s in Fig 7 .

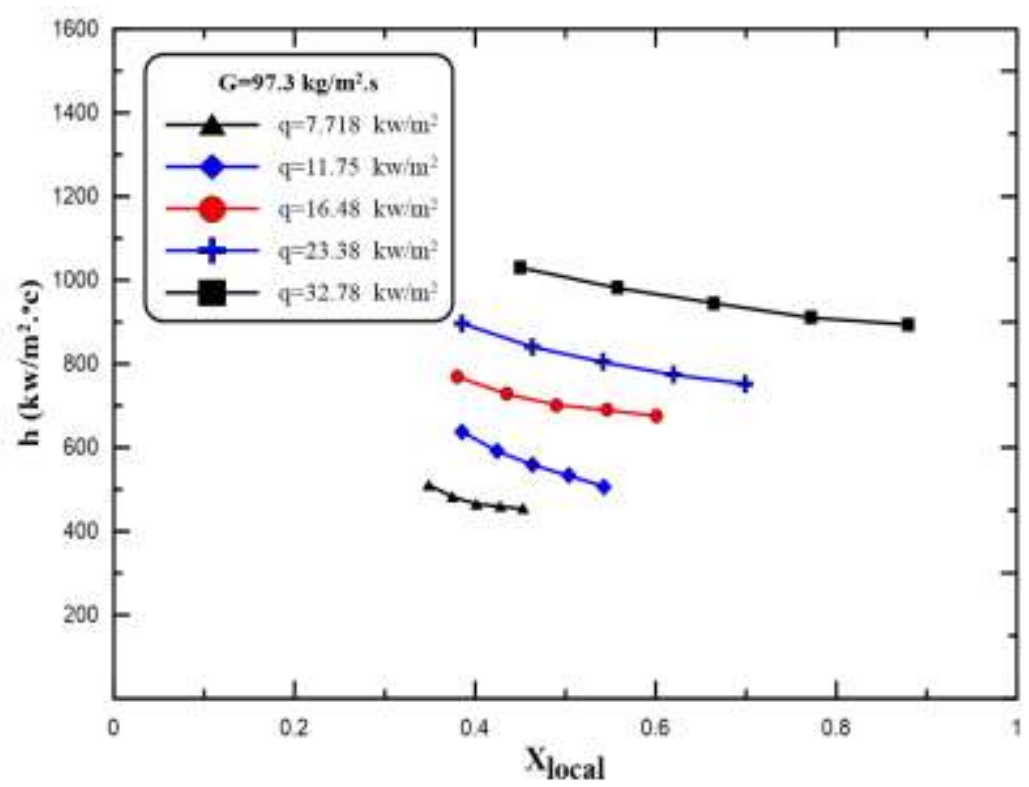

Fig 6. Effect of heat flux on local heat transfer coefficient for $\mathrm{G}=97.3$

$$
\mathrm{kg} / \mathrm{m}^{2} . \mathrm{s} \text {. }
$$

\subsection{Effect of Mass Flux on Heat Transfer}

The variations of the flow boiling local heat transfer coefficient with vapor quality at fixed heat flux $11.85 \mathrm{~kW} / \mathrm{m}^{2}$ and various mass fluxes 
97.3, 112.5 and $148.7 \mathrm{~kg} / \mathrm{m}^{2}$.s are shown in Fig. 8 and Fig.9 .The higher values of heat transfer coefficient can be observed at relatively greater mass flux $148.7 \mathrm{~kg} / \mathrm{m}^{2}$.s due to the heat transfer contribution of forced convective evaporation which depends on refrigerant mass flow rate. The same behavior of the heat transfer coefficient can be observed for heat flux $32.78 \mathrm{~kW} / \mathrm{m}^{2}$ in Fig.9.

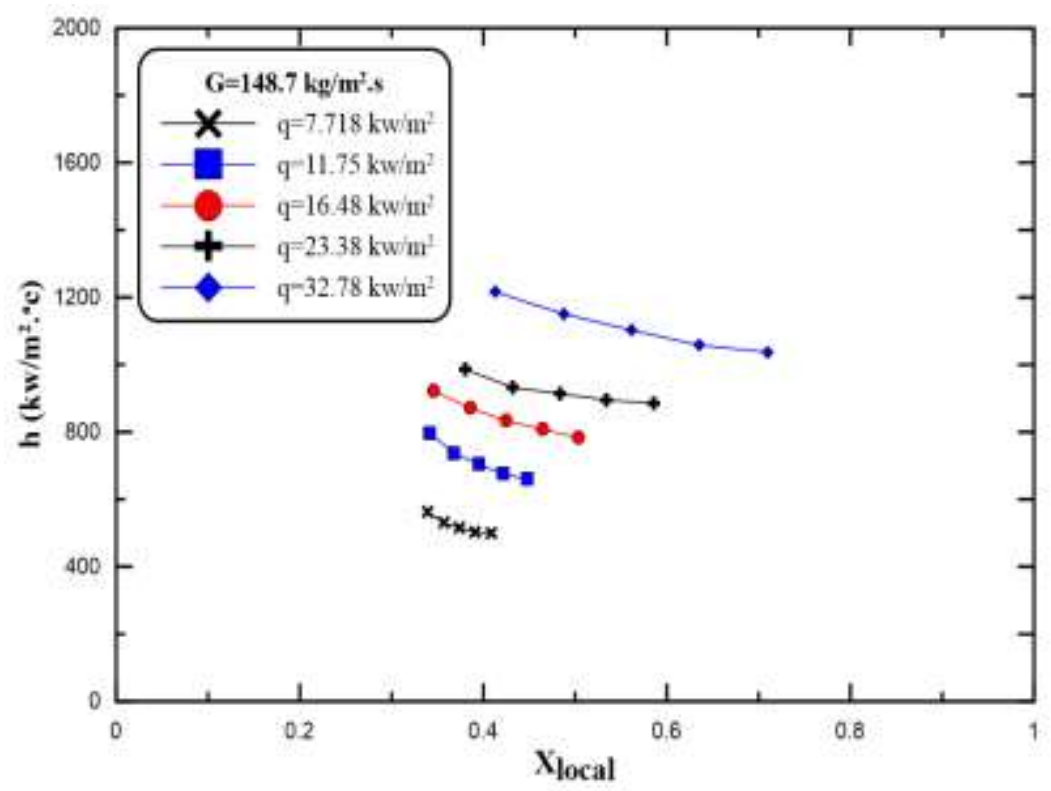

Fig 7. Effect of heat flux on the local heat transfer coefficient for $\mathrm{G}=$ $148.7 \mathrm{~kg} / \mathrm{m}^{2} . \mathrm{s}$. 
University of Thi-Qar Journal Vol.14 No.3 SEP 2019

Web Site: https://jutq.utq.edu.iq/index.php/main

Email: utj@utq.edu.iq

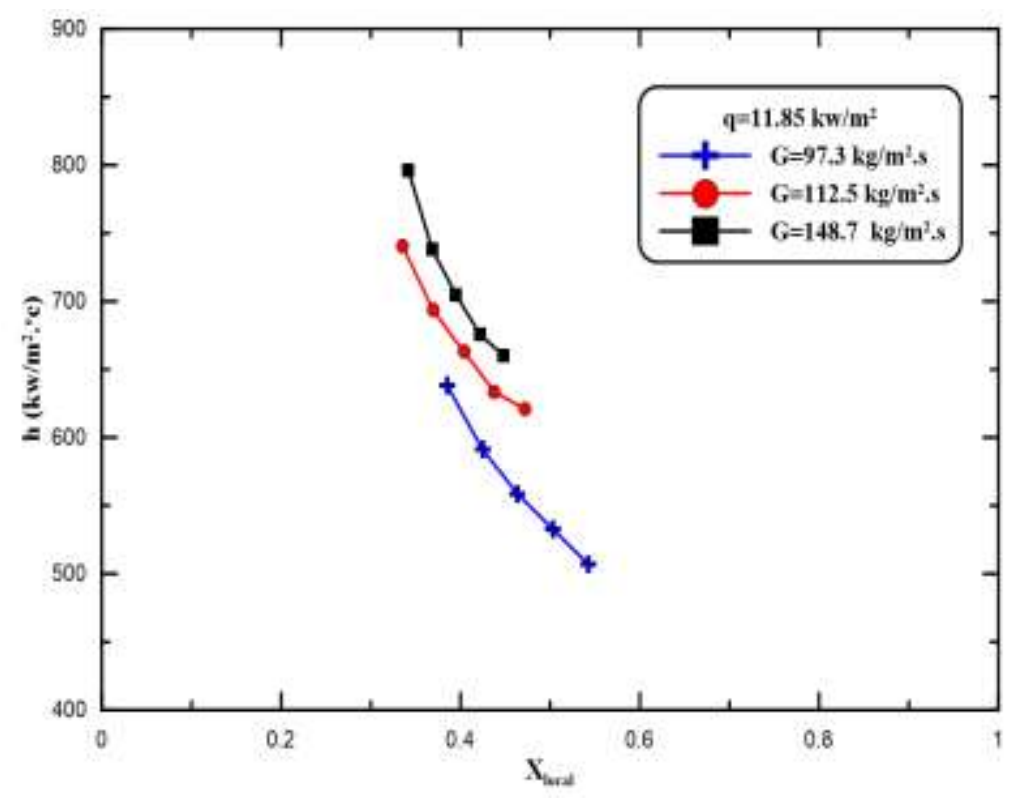

Fig 8. Effect of mass flux on the local heat transfer coefficient for $\mathrm{q}=$ $11.85\left(\mathrm{~kW} / \mathrm{m}^{2}\right)$

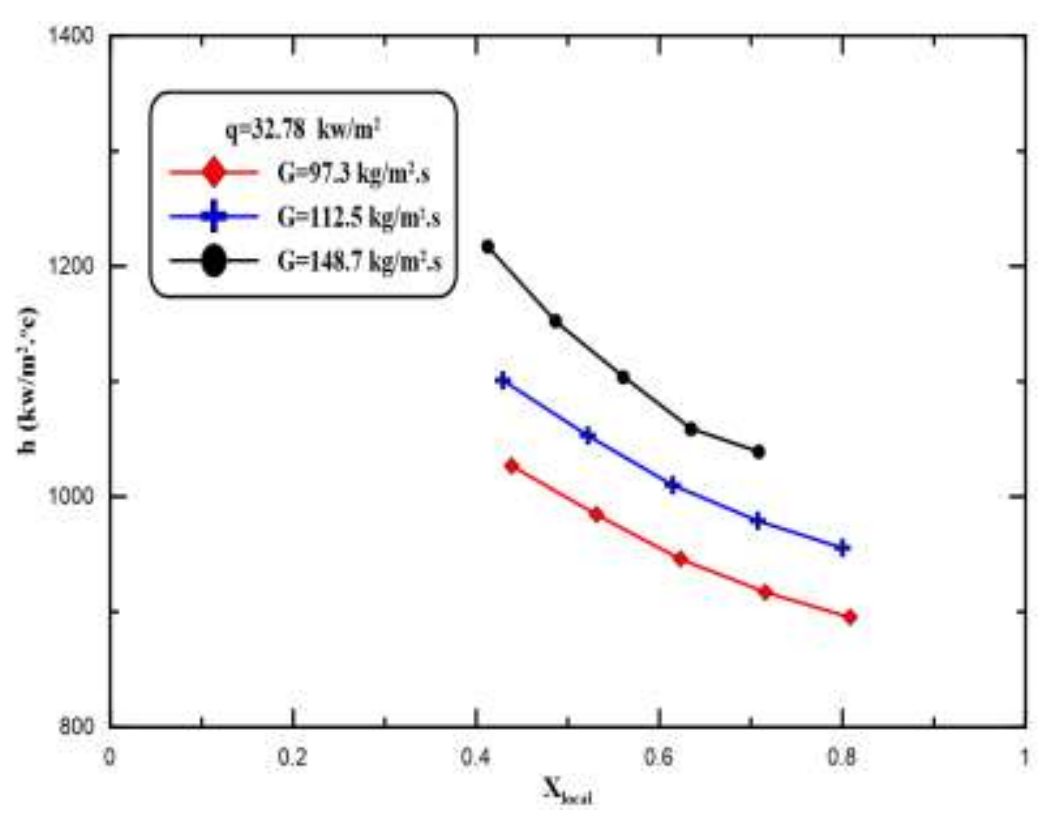

Fig 9. Effect of mass flux on the local heat transfer coefficient for $\mathrm{q}=$ $32.78 \mathrm{~kW} / \mathrm{m}^{2}$. 


\section{University of Thi-Qar Journal Vol.14 No.3 SEP 2019 \\ Web Site: https://jutq.utq.edu.iq/index.php/main \\ Email: utj@utq.edu.iq}

\subsection{Effect of Inlet Vapor Quality and Saturation Temperature on Heat Transfer}

The effect of R-134a inlet vapor quality on local heat transfer coefficient inside the evaporator tube at a constant heat flux $32.78 \mathrm{~kW} / \mathrm{m}^{2}$ and mass flux $112.5 \mathrm{~kg} / \mathrm{m}^{2}$.s is depicted in Fig.10. Three different values of the inlet vapor quality $0.3881,0.3567$, and 0.3357 were tested. It can be observed that the local heat transfer coefficient increases with inlet vapor quality along the evaporator tube due to the dominance of forced convective boiling at relatively higher inlet vapor quality. The effect of R-134a saturation temperature on local heat transfer coefficient at constant heat flux $16.48 \mathrm{~kW} / \mathrm{m}^{2}$ is illustrated in Fig.11. Three different values of saturation temperature $-20.58^{\circ} \mathrm{C},-17.31^{\circ} \mathrm{C}$, and $-15.68^{\circ} \mathrm{C}$ were tested. The increase of saturation temperature leads to a significant increase in local heat transfer coefficient as a result of decrease in wallrefrigerant temperature difference at constant test conditions in accordance with Newton law of cooling. The enhancement in local heat transfer coefficient at temperature $-15.68^{\circ} \mathrm{C}$ was $12 \%$ higher than the relatively lower saturation temperature of $-20.58^{\circ} \mathrm{C}$.

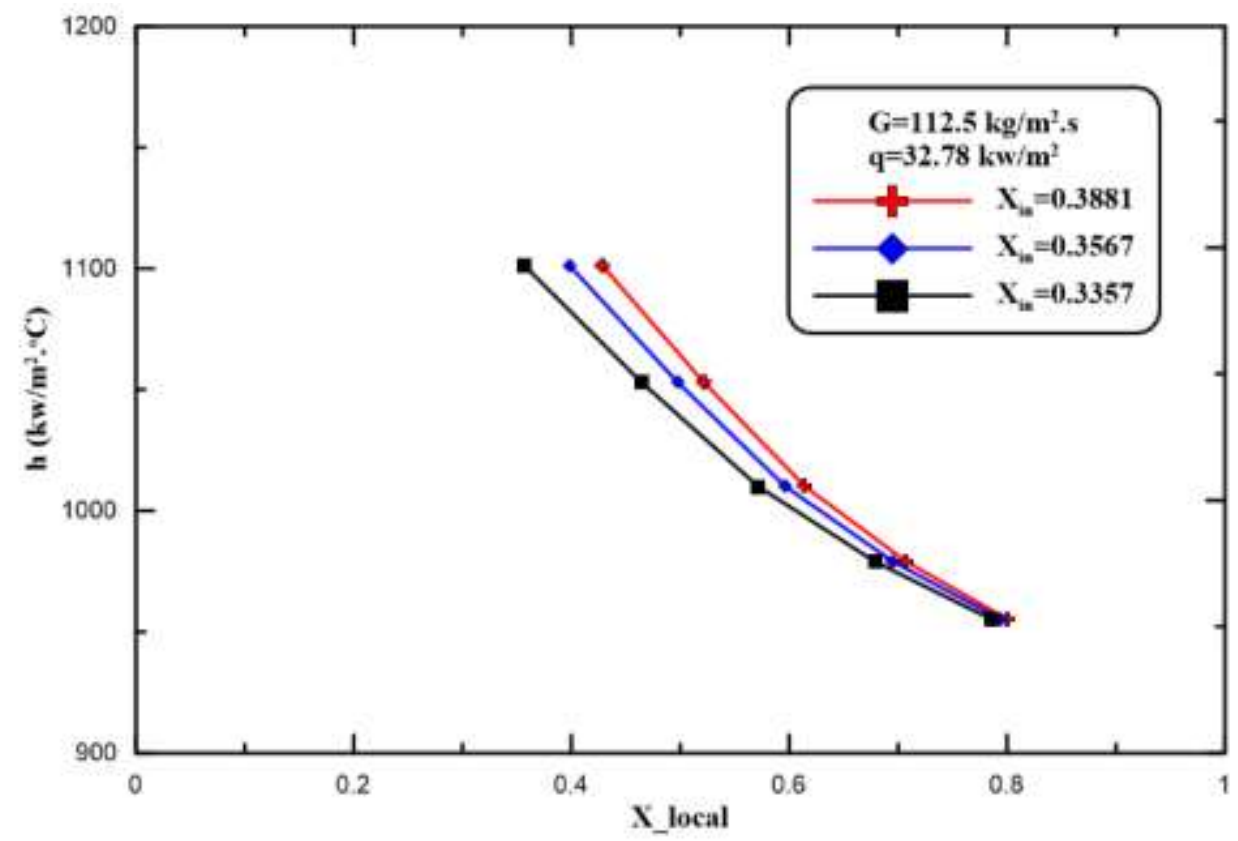




\section{University of Thi-Qar Journal Vol.14 No.3 SEP 2019 \\ Web Site: https://jutq.utq.edu.iq/index.php/main \\ Email: utj@utq.edu.iq}

Fig 10. Variation of heat transfer coefficient with refrigerant inlet vapor quality at $\mathrm{q}=32.78 \mathrm{~kW} / \mathrm{m}^{2}$ and $\mathrm{G}=112.5 \mathrm{~kg} / \mathrm{m}^{2} . \mathrm{s}$.

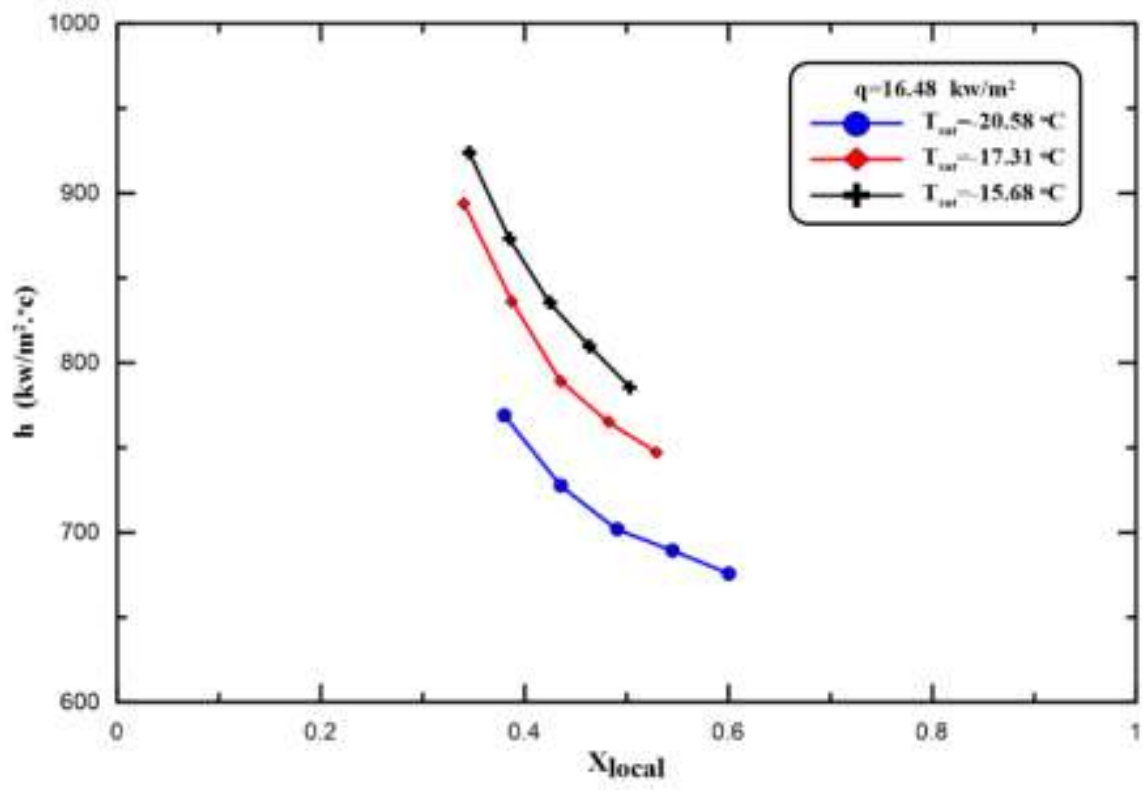

Fig 11. Effect of saturation temperature on local heat transfer coefficient for $\mathrm{q}=16.48 \mathrm{~kW} / \mathrm{m}^{2}$

\subsection{Effect of Heat Flux and Mass Flux on Pressure Drop}

The variations of pressure drop of the refrigerant flow boiling with vapor quality in the evaporator tube can be attributed to three sources, friction of fluid with tube surface, momentum change of the flow in the tube and static pressure change. The experimental results of two-phase flow boiling show that the frictional pressure drop increases with the increase in mass flux as shown in Fig. 12 and with heat flux as shown in Fig. 13 at constant test conditions. The increase in mass and heat fluxes enhance the refrigerant flow velocity and then leads to rise in frictional pressure drop along the evaporator tube. 
University of Thi-Qar Journal Vol.14 No.3 SEP 2019

Web Site: https://jutq.utq.edu.iq/index.php/main

Email: utj@utq.edu.iq

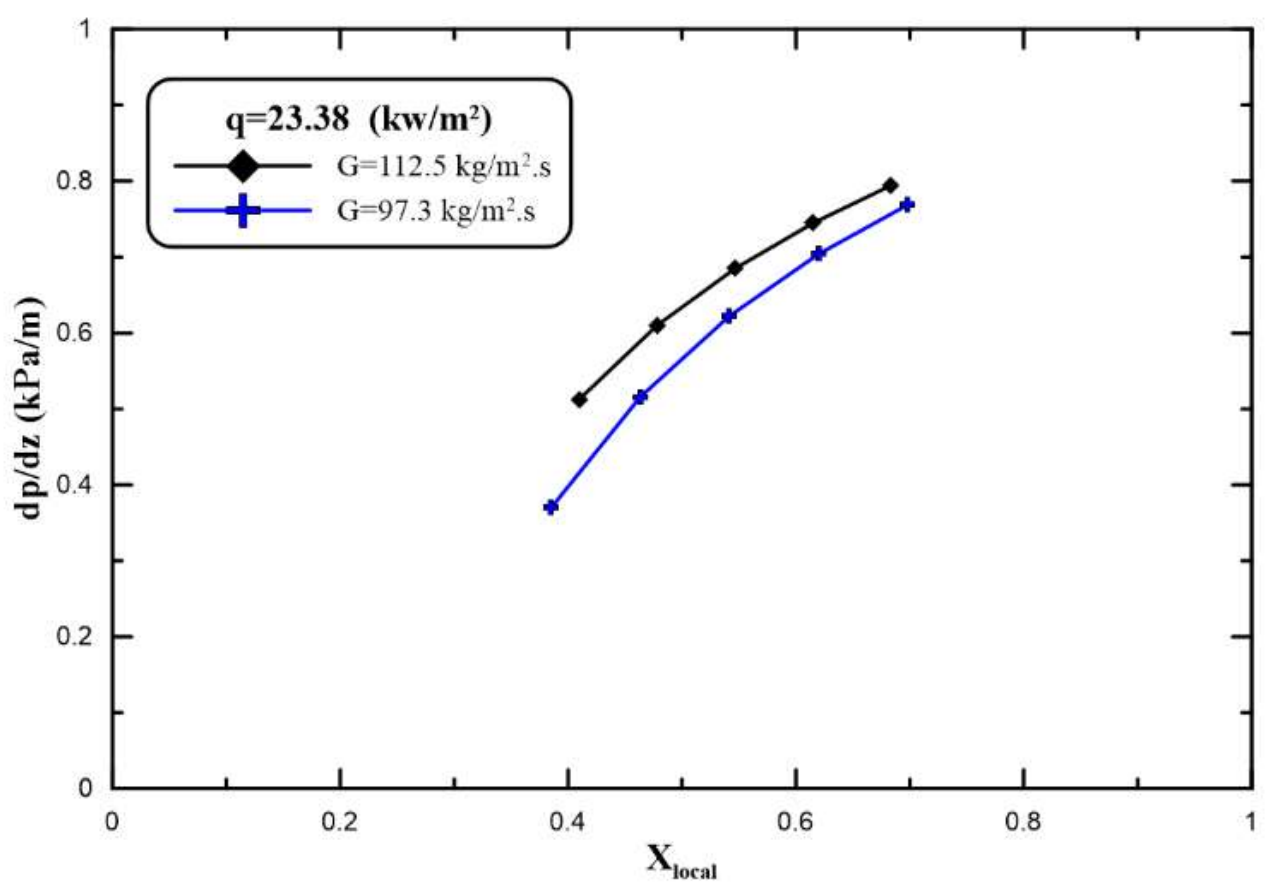

Fig. 12 Pressure drop variation as a function of vapor quality for $\mathrm{q}=23.38$ $\mathrm{kW} / \mathrm{m}^{2}$. 
University of Thi-Qar Journal Vol.14 No.3 SEP 2019

Web Site: https://jutq.utq.edu.iq/index.php/main

Email: utj@utq.edu.iq

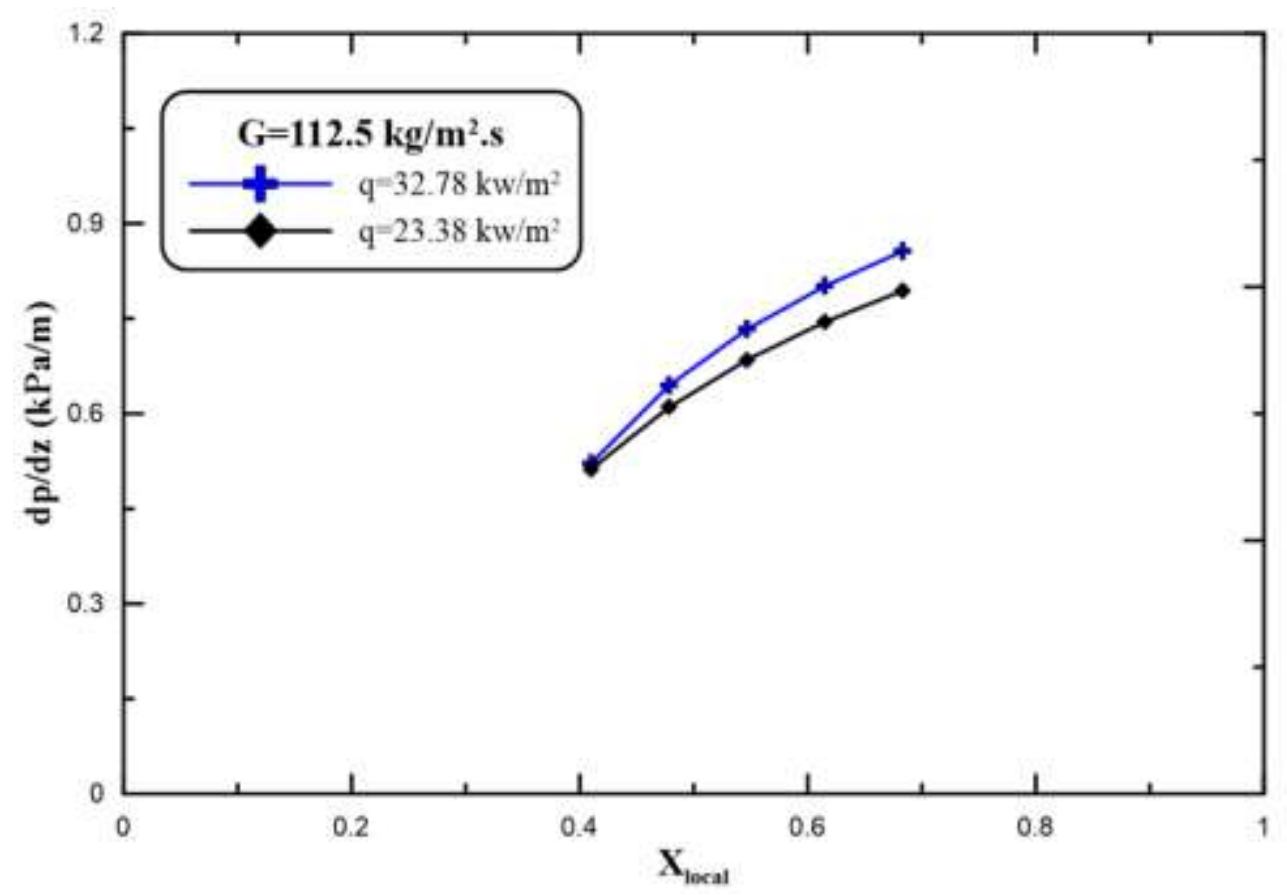

Fig 13. Pressure drop variation as a function of vapor quality for $\mathrm{G}=112.5$ $\mathrm{kg} / \mathrm{m}^{2} . \mathrm{s}$.

The Comparison between the current work results and Ong [14] results show a similar trend as illustrated in Fig. 14. The deviation in value of heat transfer coefficient is resulted from the difference in tube dimensions and operating conditions. 
Web Site: https://jutq.utq.edu.iq/index.php/main

Email: utj@utq.edu.iq

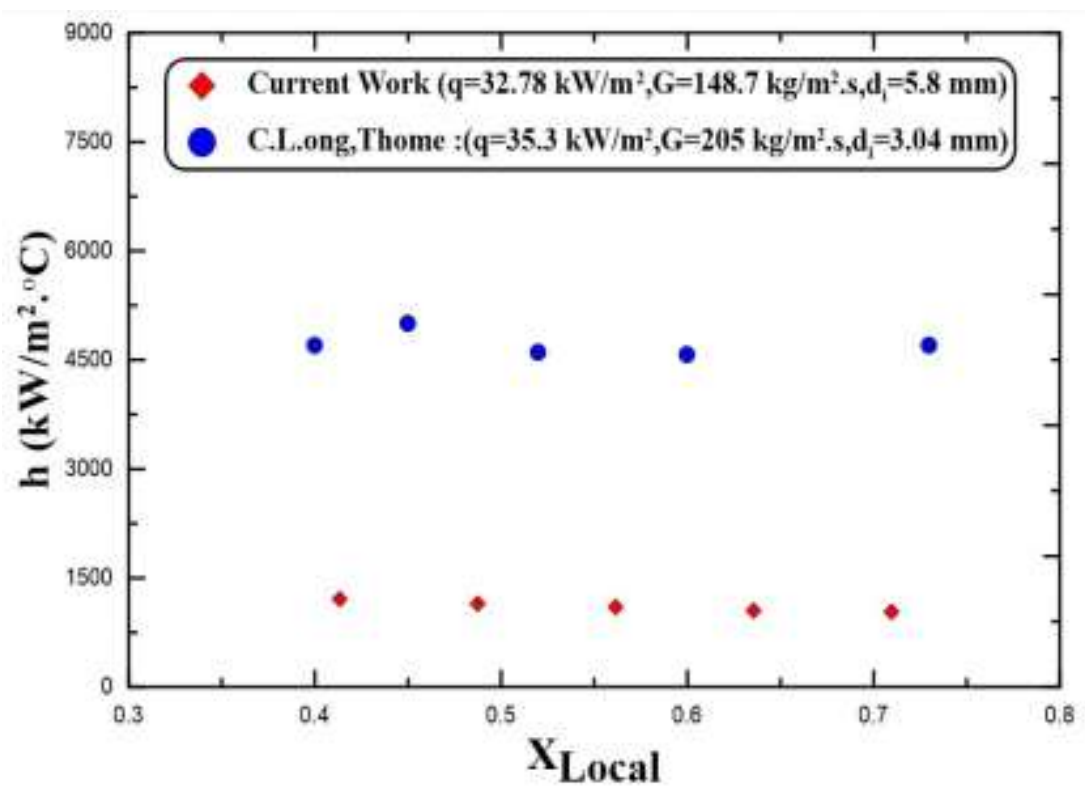

Fig 14. Comparison between the current work results and Ong [14] results.

\section{CONCLUSIONS}

1. The local heat transfer coefficient was directly proportional to the refrigerant mass flux, where the average heat transfer coefficient at relatively greater mass flux $148.7 \mathrm{~kg} / \mathrm{m}^{2}$.s was $21 \%$ higher than other mass fluxes at similar test conditions.

2. The relatively higher value of heat transfer coefficient was observed at heat flux $32.78 \mathrm{~kW} / \mathrm{m}^{2}$ with an average increase of $19 \%$ compared to the relatively lower value of heat flux $23.38 \mathrm{~kW} / \mathrm{m}^{2}$.

3. The enhancement in local heat transfer coefficient was about $6 \%$ for inlet vapor quality 0.3881 compared to the relatively lower value $0.3357 \%$.

4. The enhancement in local heat transfer coefficient at temperature $15.68^{\circ} \mathrm{C}$ was approximately $12 \%$ higher than that for the relatively lower saturation temperature $-20.58^{\circ} \mathrm{C}$.

5. The effect of increase in mass flux and heat flux on pressure drop was approximately $9 \%$ and $7.5 \%$ respectively. 


\section{NOMENCLATURE}

d Diameter of the test section tube (m)

G Mass flux $\left(\mathrm{kg} / \mathrm{m}^{2} . \mathrm{s}\right)$

g Gravity acceleration $\mathrm{m} / \mathrm{s}^{2}$

$\mathrm{h}$ Specific enthalpy $(\mathrm{kJ} / \mathrm{kg})$

$\mathrm{h}_{\mathrm{fg}}$ Latent heat of vaporization $(\mathrm{kJ} / \mathrm{kg} . \mathrm{h})$

$\mathrm{h}_{\mathrm{z}}$ local heat transfer coefficient $\left(\mathrm{W} / \mathrm{m}^{2}{ }^{\circ} \mathrm{C}\right)$

I Current (A)

$\mathrm{k}_{\mathrm{cu}}$ Thermal conductivity of tube $\left(\mathrm{W} / \mathrm{m} .{ }^{\circ} \mathrm{C}\right)$

$\mathrm{L}$ Length of the test section tube (m)

Lz Length of tube subsection (m)

$\dot{m}$ Mass flow rate $(\mathrm{kg} / \mathrm{s})$

$\mathrm{p}$ pressure $(\mathrm{Pa})$

$\dot{Q} \quad$ Heat transfer $(\mathrm{W})$

$\dot{q}$ Heat flux $\left(\mathrm{W} / \mathrm{m}^{2}\right)$

$\mathrm{T}$ temperature $\left({ }^{\circ} \mathrm{C}\right)$

V Voltage (V)

$\mathrm{x}$ Vapor quality, dimensionless

\section{Subscripts:}

b Bottom

ev Evaporator

fr frictional

i inlet

L Liquid

m Momentum

o Outlet

pr Preheater

ref Refrigerant

sat Saturation

$\mathrm{t}$ Top

ts Test section

v Vapor 
University of Thi-Qar Journal Vol.14 No.3 SEP 2019

Web Site: https://jutq.utq.edu.iq/index.php/main

Email: utj@utq.edu.iq

W Wall 


\section{University of Thi-Qar Journal Vol.14 No.3 SEP 2019 \\ Web Site: https://jutq.utq.edu.iq/index.php/main \\ Email: utj@utq.edu.iq}

\section{REFERENCES}

[1] Martin Callizo, Claudi. "Flow boiling heat transfer in single vertical channels of small diameter" Diss. KTH, (2010).

[2] Anwar, Zahid. "Flow boiling heat transfer, pressure drop and dry out characteristics of low GWP refrigerants in a vertical mini-channel" Diss. KTH Royal Institute of Technology, (2014).

[3] Patel, Giteshkumar N. "CFD Simulation of Two-phase and Threephase Flows in Internal-loop Airlift", (2010).

[4] Chen, L., Y. S. Tian, and T. G. Karayiannis. "Vertical upward flow patterns in small diameter tubes." (2005).

[5] Huo, Y., Tian S., and Karayiannis, T. G. "R134a flow boiling heat transfer in small diameter tubes." RT Edwards Inc., (2007).

[6] Mahmoud, Mohamed M., Tassos G. Karayiannis, and David BR Kenning. "Surface effects in flow boiling of R134a in microtubes." International Journal of Heat and Mass Transfer, 54, pp1516, (2011).

[7] Ali, Rashid, Björn Palm, and Mohammad H. Maqbool. "Flow boiling heat transfer characteristics of a minichannel up to dryout condition." Journal of Heat Transfer 133.8 (2011): 081501.

[8] Pike-Wilson, Emily A., Mohamed M. Mahmoud, and Tassos G. Karayiannis. "Flow boiling of R134a and R245fa in a $1.1 \mathrm{~mm}$ diameter tube." ASME 2013 11th International Conference on Nanochannels, Microchannels, and Minichannels. American Society of Mechanical Engineers Digital Collection, (2013).

[9] Fang, Xiande. "A new correlation of flow boiling heat transfer coefficients based on R134a data." International Journal of Heat and Mass Transfer ,66, (2013).

[10] Mancin, Simone, Andrea Diani, and Luisa Rossetto. "R134a flow boiling heat transfer and pressure drop inside a $3.4 \mathrm{~mm}$ ID microfin tube." Energy Procedia, 45, (2014). 


\section{University of Thi-Qar Journal Vol.14 No.3 SEP 2019 \\ Web Site: https://jutq.utq.edu.iq/index.php/main \\ Email: utj@utq.edu.iq}

[11] Li, Wei, et al. "Effects of heat flux, mass flux and two-phase inlet quality on flow boiling in a vertical super hydrophilic microchannel", International Journal of Heat and Mass Transfer,119, (2018).

[12] Collier J. G. and J. R. Thome, "Convective boiling and condensation", Third ed., Oxford University press, pp. 176, (1994).

[13] Copetti, J. B., Macagnan, M. H., Zinani, F., and Kunsler, N. L., "Flow boiling heat transfer and pressure drop of R-134a in a mini tube: an experimental investigation", Experimental Thermal and Fluid Science, Vol. 35, pp 636-644, (2011).

[14] Ong, C. L., and J. R. Thome. "Macro-to-microchannel transition in two-phase flow: Part 2-Flow boiling heat transfer and critical heat flux." Experimental thermal and fluid science 35.6: 873-886. (2011). 